\title{
Psycho Social Aspects of Tribal Unwed Mothers
}

\author{
Ginu George Powathil ${ }^{1}$, Nirmala Bergai Parthsarathy ${ }^{2 *}$
}

\section{Ginu George Powathil, Nirmala Bergai Parth- sarathy* \\ Department of Psychiatric Social Work, Govindswamy Centre, next to State Bank of Mysore, NIMHANS, Benga- luru-560 029, Karnataka, INDIA.}

\section{Correspondence}

Nirmala Bergai Parthsarathy,

Additional Professor, Department of

Psychiatric Social Work, Govindswamy Centre, next to State Bank of Mysore, NIMHANS, Bengaluru-560 029, Karnataka, INDIA.

Mobile no: 9448338549 or 08026995703

Email: drbpnirmala@gmail.com

History

- Submission Date: 05-11-16

- Revised Date: 09-04-17

- Accepted Date: 26-04-17

DOI : 10.5530/ijmedph.2017.2.21

Article Available online

http://www.ijmedph.org/v7/i2

\section{Copyright}

(C) 2017 Phcog.Net. This is an openaccess article distributed under the terms of the Creative Commons Attribution 4.0 International license.

\begin{abstract}
Introduction: The presence of unwed mothers is a major problem that the tribal communities face today in Wayanadu. They are experiencing Multiple Social, Psychological, Economical and Educational disadvantage. The authors have studied socio-demographic profile and assessed the Self-esteemand psychological distress of this vulnerable group. Methods: the study follows cross sectional descriptive design, a sample of 40 respondents were interviewed through a proforma to collect socio-demographic details and administered Rosen Berg Self-esteem scale and self-reporting questionnaire to assess psychological distress. The data was analysed using descriptive statistics and correlation. Results: The socio demographic profile shows that majority of the unwed women are illiterate ad in the productive age group with low income and there is negative co-relation between self-esteem and psychological distress. Conclusion: Poor self-esteem is associated with a broad range of mental disorders like depression, suicide, eating disorders and anxiety. It is argued that an understanding of the development of self-esteem, its active protection and promotion are critical to the both mental and physical health. Hence, it hoped that the present study will be of great use in alleviating the distress associated with the unwed motherhood and promoting their Self-esteem and quality of life by addressing their psycho social concerns.
\end{abstract}

Key words: Self Esteem, Psychological Distress, Tribal Unwed Mother, Poverty, Vulnerability.

\section{INTRODUCTION}

Tribals constitute $8.61 \%$ of the total population of the country, numbering 104.28 million $^{1}$ and cover about $15 \%$ of the country's area. The fact that tribal people need special attention can be observed from their low social, economic and participatory indicators. ${ }^{2}$

The name Wayanad is believed to have derived from the word Vayal-Nadu-The land of paddy fields. The native Adivasis mainly consist of various sects of Paniyas, Kurumas, Adi Yas, Kurichiyas, Ooralis, Kattunaikks etc. they have their own special life styles, culture, customs, traditions and religious practices. Majority of the tribes lives under poverty line, the tribes follow simple occupation based on simple technology. Most of the occupation falls in the primary occupations such as hunting, gathering and agriculture. The technology they use is also primitive and there is no surplus profit in their economy. They believe in collective ownership of land. Accept traditional leaders, with the beginning of British colonialism in India opened the tribal lands to be exploited by money lenders, Zamindars and Traders who disturbed the natural life cycle of tribal ecology and tribal life, in Kerala especially in Waynadu women enjoyed equal status with men and were the corner stone of social structure. Divorce and widow remarriage were permitted. Women were considered as asset for the parents as bride price was practiced, all these customs and traditions underwent transformation. Tribal girls are recruited as casual labourers inthe plantations and are sexually abused by their masters and fellow workers with fake promise of marriage. ${ }^{3}$ They become pregnant they are left to defend themselves, many of them are forced to take up sex work for their survival they had severe relationship difficulties and dissatisfaction with family, relatives and neighbours. Unwed mothers are likely to have less social contact and access to community information. ${ }^{4,5}$ Grace Henryin her study on psychological profile of unwed mothers viewed their future as uncertain, most of them had experienced a lot of distress in their future. They were devastated about worried what the future would hold for them. The Unwed motherhood among the tribe's is most challenging to public health experts, educationists and social workers. ${ }^{4-6,7}$

Because of lack of knowledge about menstruation, reproductive physiology and birth control methods. Health education and sex education is most important for the tribal women. ${ }^{8}$ Family burden and less literacy forced them to indulge in sexual contact after a promise of marriage, for sexual pleasure, curiosity or economic gains. They were the victims of rape and Out-of-wedlock pregnancy. ${ }^{9}$

Wayanadu is a home to 2,000 unwed mothers, eking out perilous existence in the shadow of shame. There are sexually abused and abandoned women in tribal hamlets all over Kerala, but this district, with its 17.1
Cite this article : Powathil GG, Parthsarathy NB. Psycho Social Aspects of Tribal Unwed Mothers. Int J Med. Public Health. 2017; 7(2):107-110. 
percent tribal population, has the greatest number. A majority of them are illiterate, innocent and gullible. It is easy to cheat them. According to the report of Joseph, any exposure to outside world is leading them to misery. ${ }^{3}$

\section{MATERIALS AND METHODS}

The aim is to study the socio demographic profile of unwed mothers who belong to tribal community through an Interview Schedule and assess two psychological parameters, Self-esteem and psychological distress and their correlation with demographic factors as well as with each other. The present study followed a cross sectional descriptive research design it was conducted with all the tribal unwed mothers in Wayanadu distrct, Kerala, such as Tirunelli, Muthanga, Sultan bathery and Pulpally village of Wayanadu district. The sample consists of 40 respondents The researcher took the help of the volunteers of Aadivasi Yuvajana Samithy who worked in a community development agency, devoted for tribal welfare, explained the purpose of the study and obtained their consent before administering the tools. The questionnaires were administered through interview with the mothers. The sample had to full fill the inclusion criteria of unwed mothers remaining single after having a child, the participation was purely voluntary only those who had given their consent were included in this study. It was made clear to the participants that no monetary benefits will be given. After seeking the consent to participate, the date and time was fixed.

\section{Measures}

The researcher had prepared the socio demographic interview schedule including age, name, religion, caste, educational qualification, living status, number of children, income, occupation and use of substances along with the following tools.

Rosenberg Self-esteem Scale (RSES) by Rosenberg, ${ }^{10}$ consisted of 10 question which were closed ended, the reliability of the scale on coefficient of reproducibility was found to be 0.92 , indicating excellent internal consistency and validity. Each item is answered on a four-point Likert scale - from strongly agree (3) to strongly disagree (0). Five items are reverse scored - from strongly disagree (3) to strongly agree (0). Test - retest correlation are typically in the range of 0.82 to 0.88 and Cranach's alpha for various samples are in the range of 0.77 to 0.88 , higher the score, higher the self-esteem, scores below 15 suggest low self-esteem.

Self-Reporting Questionnaire (SRQ) is a 20 item screening instrument for the detection of psychiatric disorders. ${ }^{11}$ It has reliability coefficient of 0.792 it has been widely used and validated in many cultural contexts. ${ }^{12}$ A cut-off score of 8-9 is commonly accepted in many Indian studies. ${ }^{13,14,15}$ Which was also adopted by the current study. A score below 9 indicates the respondent to enjoy good mental health or being a 'non-case', whereas a score above 9 indicates the possible presence of mental health difficulties which warrant psychological evaluation.

\section{Analysis of the data}

The data was analysed using descriptive statistics like mean and standard deviation, Karl Pearson's Coefficient of Correlation was used to find the relationship between psychological distress and self-esteem. Non parametric test such as Kruskal Wallis test and Mann Whitney u test was also used in this study while comparing self-esteem with socio demographic variable

\section{RESULTS}

\section{Socio demographic details}

The analysis of the socio demographic profile of the unwed mothers indicates that age of the respondents range from 21-50 years. Majority of respondents (42.5\%) were belonging to the age group of 31-40. Further analysis on social stratification revealed that all the respondents (100\%) were Hindus. Distribution of respondents according to their caste shows that majority (35\%) of respondents belonged to Paniya community compared with Aditya community and Kurichiya community. Most of the tribal women $(62.5 \%)$ were illiterate. Majority of respondents $(62.5 \%)$ were staying with their children than staying with their parents and staying alone. Majority of (60\%) respondents had one child. Most of respondents $(97.5 \%)$ were working as agricultural labourers. Majority of respondents (85\%) were getting an amount of Rs. 500 and below. With regard to substance use, majority of respondents (57.5\%) were reported to have nicotine use (Table 1 ).

The results show that $87.5 \%$ of respondents have high Self-esteem and $12.5 \%$ of respondents to have low self-esteem. Mean of Self-esteem of respondents is 17.12 and standard deviation is 2.05 .

\section{Self esteem}

Table 2 indicated majority (87.5\%) of the respondents reported to have high self-esteem. Respondents who were belonging to the age category of 41-50 reported to have more self-esteem. (Mean value $=18 \pm 1.58$ ) compared with other age groups. Respondents earnings Rs. 501 and above reported to have more Self-esteem (Mean value $=17.67 \pm 2.54$ ) than the

\begin{tabular}{|c|c|c|c|}
\hline \multicolumn{2}{|c|}{ Variables } & \multirow{2}{*}{$\begin{array}{c}\text { Frequency } \\
\qquad 10\end{array}$} & \multirow{2}{*}{$\begin{array}{c}\text { Percentage } \\
25\end{array}$} \\
\hline \multirow{3}{*}{ Age } & $21-30$ & & \\
\hline & $31-40$ & 17 & 42.5 \\
\hline & $41-50$ & 13 & 32.5 \\
\hline \multirow[t]{2}{*}{ Religion } & Hindu & 40 & 100 \\
\hline & Paniya & 14 & 35 \\
\hline \multirow{4}{*}{ Caste } & Adiya & 9 & 22.5 \\
\hline & Kurichiya & 3 & 7.5 \\
\hline & Others & 14 & 35 \\
\hline & Illiterate & 25 & 62.5 \\
\hline \multirow{2}{*}{ Education } & Primary education & 11 & 27.5 \\
\hline & $\begin{array}{l}\text { Higher secondary } \\
\text { education }\end{array}$ & 4 & 10 \\
\hline \multirow{3}{*}{$\begin{array}{c}\text { Living } \\
\text { arrangements }\end{array}$} & Alone & 6 & 15 \\
\hline & With children & 25 & 62.5 \\
\hline & With parents & 9 & 22.5 \\
\hline \multirow{3}{*}{$\begin{array}{l}\text { Number of } \\
\text { children }\end{array}$} & One & 24 & 60 \\
\hline & Two & 15 & 37.5 \\
\hline & Three & 1 & 2.5 \\
\hline \multirow{2}{*}{ Occupation } & Agricultural workers & 39 & 97.5 \\
\hline & House maid & 1 & 2.5 \\
\hline \multirow{4}{*}{ Income } & 500 and below & 34 & 85 \\
\hline & $501-1000$ & 4 & 10 \\
\hline & $1000-1500$ & 1 & 2.5 \\
\hline & $1501-2000$ & 1 & 2.5 \\
\hline \multirow{3}{*}{ Substance use } & No substance use & 14 & 35 \\
\hline & Drugs & 3 & 7.5 \\
\hline & Nicotine & 23 & 57.5 \\
\hline
\end{tabular}




\begin{tabular}{|cccc|}
\hline \multicolumn{3}{c}{ Table 2 :Self-esteem tribal Unwed mothers } \\
Domain & Items & Frequency & Percentage \\
\hline \multirow{2}{*}{ Self esteem } & Low self esteem & 5 & 12.5 \\
& High self esteem & 35 & 87.5 \\
\hline
\end{tabular}

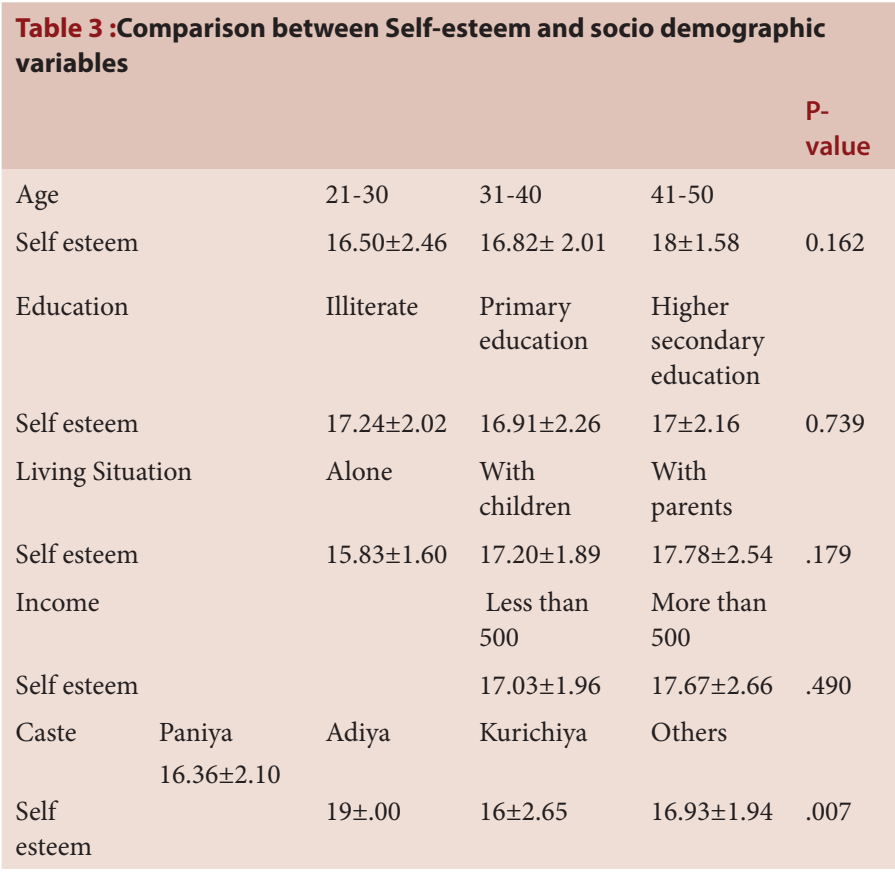

\begin{tabular}{|c|c|c|c|}
\hline Domain & Items & Frequency & Percentage \\
\hline \multirow{2}{*}{$\begin{array}{l}\text { Self reporting } \\
\text { questionnaire }\end{array}$} & No distress & 16 & 40 \\
\hline & Distress & 24 & 60 \\
\hline
\end{tabular}

other two groups. Aditya tribe had reported more Self-esteem (Mean value $=19 \pm 0.0$ ) than other three groups (Table 3 ).

\section{Psychological distress}

Table 4 Psychological distress depict that $60 \%$ of the population was suffering from psychological distress and $40 \%$ of respondents reported that they didn't have any psychological distress. Mean of self-reporting questionnaire is 9.2 and standard deviation is 4.3 . There was significant negative correlation between psychological distress and Self-esteem $(r=-.410$, pvalue $=.010$ ). Karl Pearson's correlation was used to understand the relationship between psychological distress and self-esteem.

\section{DISCUSSION}

Most of the tribal mothers are illiterate the tribal language do not have script, the tribal hamlets are too far away from schools, mother force their children to work as labourers in the field than go to school. ${ }^{16}$ It also states that aboriginal mother shave significantly low education levels. Most of the tribal mother $60 \%$ had one child. Malnutrition and chronic anaemia might be the cause of early death. ${ }^{17}$ The rate of home delivery is $81.8 \%$ poor antenatal care may lead to high infant mortality rate, the unwed girl seeks pregnancy termination beyond the legitimate period which is no longer possible. In these instance they often abandon or kill the child several crude and in human methods were employed to eliminate infant soon after birth the novel method of late is to put grain of rice before husking to block the breath of child to bring about instantaneous death. The small size of the family can also be observed through unsafe delivery methods reflecting financial backwardness (illegal monetary involvement at hospitals/ transportation charge), location and terrain of abode with less access to transportation, fear of moving out on such occasions, fear of involving hospital personnel in such occasions, traditional beliefs or customs that restrict them, the attitude of medical staff and related authorities, lack of emergency obstetric services in Primary Health Centres (PHCs) and Community Health Centres (CHCs), the perception that the process is normal and there is no need of seeking institutional support. ${ }^{19}$

Regarding income, our study is in line with the study reported by Parvath et $a l^{18}$ that Kerala women Commissionsurvey in Kodencherry and Karassery panchayats in Kozhikode district showed hardships that dogged tribal people were mainly due to lack of many basic facilities. The survey, which covered 382 families, found the average monthly income of nearly 83 percent was as low as Rs. 1000 .

Majority of the respondents report to have nicotine use $(57.5 \%)^{19}$ reported that it is widely prevailing in Pandya's. There is no social stigma attached to drinking, ganja, or arrack and there is no social pressure to decry the habit ${ }^{20}$ and noted that substance use leads to high psychological risk for developing mental health problems. ${ }^{21}$ Also asserted that women who abuse substance have more stress full life ways.

Majority of the respondents (87.5\%) reported to have high self-esteem. It might be because most of the Unwed mothers are in a productive age group (31-50) and earn their living independently rather than depending on others, even though the prevalence of low Self-esteems small in proportion it cannot be ignored taking into cognizance the public health impact of the unwed tribal mothers. ${ }^{22}$ Which reported that work enhances the Self-esteem of women. Higher self-esteem among working women as compared to homemakers could be due to the fact that these women would have something positive (such as higher status and economic independence) in an opportunity to work outside the home. A feeling of contributing to the welfare of their families as well as society might enhance their self-esteem. ${ }^{23} \mathrm{He}$ revealed that professional working women have higher gratification then housewives. He stated that there exist significant differences on Self-esteemand self-efficacy among working women and homemakers. The reason could be that work provides a woman with healthy self-esteem, self-efficacy confidence, independence and satisfies her needs for social recognition, freedom, power and individuality.

There is a great prevalence of unwed motherhood in that community, it is not an unusual phenomenon, the chances of acceptance of unwed motherhood by the respondents might also be the reason for high selfesteem. The mean score of this age group regarding Self-esteem was 18 and standard deviation 1.58 there was no significant difference across the age groups with respect to Self-esteemand it also shows that as age increases Self-esteem was also increase. This might be because in early stages of motherhood respondents would have shame guilt and uncertainty about their future, in middle and later stages they would get support from their children and be financially secure. This is contrary to the study by ${ }^{24}$ state that low sense of self worth was seen in single mothers. Research also indicates that being alone and lacking severe commitment from the part of Childs father effect the mother self esteem..$^{25,26}$

\section{Limitations}

In the present study, the sample size was only 40 , so the results cannot be generalized to a larger population. It was difficult to get the respondents since it was a highly sensitive area of study. Collection of information from the respondents was difficult since they were guarded and going to the community itself was not easy for the researcher since there were stigma associated with unwed motherhood. Though the self reporting 
questionnaire is ideally supposed to be self-administered, as the tribal mothers were illiterate or not educated enough to do so, it was filled up through interview by the investigator.

\section{Implication of the study}

It helps to draw a framework of intervention module required in providing psycho social care for unwed mothers in a community setting. It gives an insight of need based programs addressing their concerns. The tribal's need social advocacy and legal aid services the PHCs in the tribal areas should have adequate medical staff and health workers and adequate supply of generic drugs there is a need for tribal peer educators in health related issues. Creation of tribal specific policies addressing the core issues Development of Information Education Communication (IEC) and Behaviour Change Communication (BCC) materials tailor made for tribal community through intense research in this area. The role of hygiene, nutrition, alcoholism and change in lifestyle is the emergent need.

\section{CONCLUSION}

The study indicates that age, education, income and living arrangements are not contributing to self-esteem, hence we should explore other factors which may influence Self-esteem probably basic necessities, social security benefits, emotional support which may influence Self-esteemsSelf-esteemand psychological distress are inextricably linked, so that by intervening these areas we may be able to enhance self-esteem, reduce psychological distress and improve the quality of life of the tribal unwed mothers.

\section{CONFLICT OF INTEREST}

There is no conflict of interest.

\section{REFERENCES}

1. Manjunath BT. Tribal Entrepreneurship in India, Public Welfare Schemes 2015 Role of Social Work and Commerece in Transforming India. Gurushree College of Commerce and Social Work, published 2016.

2. Jeryda Gnanajane Eljo JO., Janas Mathew. A study on mental health among tribal women. Women and Mental Health, NIMHANS Publication 2010.

3. Joseph J. Some relief at last for unwed tribal mothers. Retrieved on 12th December 2011 from http://tehelka.com/story.

4. Lukose K. A study on the psychosocial problems of tribal unwed mothers of Wayanadu, Kerala : HiLDA Trust, Unpublished 2004.

5. Grace Henry CG. Psycho social profile of unwed mothers; Dissertation Unpublished, NIMHANS, Bengaluru 2004.

6. Jose PJ, Davidson KA, Joseph SJ, Sabu KU, Cherain A, Sebastian J. (2010). Unwed Tribal Motherhood in Wayanadu, Kerala (India): Exploring the contexts of stigmatization and discrimination and its implication on psychological wellbeing and social life: A Mixed Method Study. Centre for Social Work Research and
Practice-India

7. Aerthayil, M Impact of Globalisation on Tribals: In the context of Kerala. Indian Social Institute, Bangalore by Rawat Publications, 2008.

8. Chhabra S, Madondo TT, Duggan R, Adejumo O, Chandra-Mouli V, et al. A step towards helping mothers with unwanted pregnancies. Indian Journal of Maternal and Child Health. 1992;3(2):41-2.PMid:12288486.

9. Singh S, Singh A. Psycho-social correlates of unwed mothers. Indian Journal of Clinical Psychology. 1981.

10. Rosenberg M. Society and the adolescent self-image. Princeton, NJ: Princeton university press; 1965.https://doi.org/10.1515/9781400876136.

11. Beusenberg M, Orley JH, World Health Organization. A User's guide to the selfreporting questionnaire (SRO.

12. Harpham T, Reichenheim M, Oser R, Thomas E, Hamid N, Jaswal S, Ludermir A, Aidoo M. Measuring mental health in a cost-effective manner. Health policy and planning. 2003;18(3):344-9. https://doi.org/10.1093/heapol/czg041; PMid:12917276.

13. Deshpande SN, Sundaram KR, Wig NN. Psychiatric disorders among medical inpatients in an Indian hospital. The British Journal of Psychiatry. 1989;154(4):5049.https://doi.org/10.1192/bjp.154.4.504; PMid:2590781.

14. Kortmann FR, ten Horn S. Comprehension and motivation in responses to a psychiatric screening instrument. Validity of the $\mathrm{SRO}$ in Ethiopia. The British Journal of Psychiatry. 1988;153(1):95-101.https://doi.org/10.1192/bjp.153.1.95; PMid:3224257.

15. Kumbhar UT, Dhumale GB, Kumbhar UP. Self-Reporting Questionnaire as a Tool to Diagnose Psychiatric Morbidity. National Journal of Medical Research. 2012;2(1):51-4.

16. Byrd RR, Fleischhacker, Ramachandran SG, Vu M, Ries A, et al. Tools for healthy tribes: improving access to healthy foods in Indian country. American journal of preventive medicine. 2012;43(3):123-129.https://doi.org/10.1016/j amepre.2012.05.015; PMid:22898161 PMCid:PMC3431552.

17. Sharma S, Rani R, Samkaria M. Prevalence of Aneamia and Malnutrition among Gaddi Girls of Chamba and Kangra District of Himachal Pradesh. Stud. Tribes Tribals. 2007;5(2):139-42.

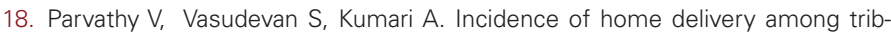
als of Wayanad. National Journal of Professional Social Work. 2013:4(1-2):24-30

19. Harikrishna K. S. Unwed Tribal Mothers Seek Aid. Retrieved on 16th January from http://www.ipsnews.net/2011/05/india-unwed-tribal-mothers-seek-aid; 2011

20. Kumar H, Varghese J. Women's empowerment, issues, challenges, and strategies: a source book. Daya Books; 2005.

21. Ginu George P. Psychosocial Aspects of Tribal Unwed Mothers, M.Phil Dissertation, NIMHANS, Unpublished 2012

22. Buc P. (2001). The dangers of ritual: between early medieval texts and social scientific theory (p. xi272). Princeton: Princeton University Press.

23. Sachdeva S, Malhotra S. Working women: A psychological perspective. Asian Journal of Psychology and Education. $2001 ;(24)$ 30-31

24. Park J, Liao T. The effect of multiple roles of South Korean married women professors: Role changes and the factors which influence potential role gratification and strain. Sex roles. 2000;43(7):571-91. https://doi. org/10.1023/A:1007175601706.

25. Elfhag K, Rasmussen F. Food consumption, eating behaviour and self-esteem among single $v$. married and cohabiting mothers and their 12-year-old children. Public health nutrition. 2008;11(09):934-9. https://doi.org/10.1017/ S1368980008002449; PMid:18489812.

26. Gopal BB. Professionally employed women and homemakers on Self-esteemand self efficacy. International Journal of Social Impact. 2016;1(1):26-31.

Cite this article : Powathil GG, Parthsarathy NB. Psycho Social Aspects of Tribal Unwed Mothers. Int J Med. Public Health. 2017; 7(2):107-110. 